\title{
Dialogia ja vertaisuus mentoroinnissa
}

\author{
MERJA KARJALAINEN, HANNU L.T. HEIKKINEN, RAUNO HUTTUNEN \\ \& MARJATTASAARNIVAARA
}

\begin{abstract}
Onko tasavertainen dialogi mahdollista mentoroinnissa? Ehdotamme mentoroinnin tarkasteluun mallia, joka auttaa välttämään toisaalta autoritaarisuuden ja hierarkkisuuden, toisaalta naiivit odotukset täydellisestä tasa-arvosta.

Tarkastelemme dialogisuuden mahdollisuutta mentoroinnissa kolmella eri tasolla eksistentiaalisella, episteemisellä ja juridis-eettisellä Mentorointi voisi parhaimmillaan olla kahden inmisen välistä vuorovaikutusta, joka perustuu vastavuoroiseen luottamukseen ja toisen tietojen, taitojen ja osaamisen arvostamiseen. Mentoroitavan ja mentorin dialogin lähtökohtana on ennen muuta vastavuoroinen tunnustuksen antaminen eksistentiaalisella tasolla.
\end{abstract}

Käsityöläisten ja taiteilijoiden kehitystä ovat vuosituhansien ajan ohjanneet mentorit. He ovat tukeneet lahjakkuuksia ja säilyttäneet mentoroinnilla ammattitaidon. Lisäksi hallitsijat ja muut poliittisen vallan käyttäjät ovat mentoroinnin avulla kasvattaneet uusia hallitsijoita. (Darwin 2000, 197-198; Juusela, Lillia \& Rinne 2000, 14; Nakari, Porenne, Mansukoski \& Huhtala 1998,6 .) Viime aikoina mentoroinnin suosio on kasvanut nopeasti eri aloilla niin kansainvälisesti kuin Suomessakin. Se on saavuttanut vahvasti suosiota esimerkiksi talous- ja yrityselämässä (mm. Tunkkari-Eskelinen 2005; Vuorinen 2004), opettajien koulutuksessa (Baldassare \& Laneve 1998; Jokinen \& Sarja 2005; Heikkinen 2005c) ja aikuiskoulutuksessa (Heikkinen 2005ab). Samalla myös mentoroinnin käsite näyttää olevan jatkuvassa uudelleenmuotoutumisen tilassa (esim. Leskelä 2005, 27).

Mentorointi on vuorovaikutussuhde, jossa kokeneempi henkilö, mentori, ohjaa, tukee ja auttaa vähemmän kokenutta, mentoroitavaa tai aktoria, ammatillisen kasvun kysymyksissä. Mentori on usein kokeneempi ja osaavampi henkilö kuin aktori, ja hän antaa vapaaehtoisesti oman osaamisensa aktorin käyttöön. Näin mentorointi voidaankin nähdä keinona asiantuntijuuden ja hiljaisen tiedon siirtämiseen. Mentorointi on vastavuoroista ajatusten vaihtoa, keskustelua ja dialogia, jossa parhaimmillaan molemmat osapuo- let oppivat. Mentorin rooli jokaisen mentorin itsensä rakentama - mitään valmista mallia mentoroinnille ei ole.

Mentoroinnin muotoja ovat mm. yksilö-, vertais-, ryhmä- ja telementorointi. Mentorointisuhteita on työpaikoilla johtajista työntekijöihin. Mentorointia sovelletaan oppilaitoksissa opiskelijoiden ohjauksessa opintojen alkuvaiheessa, työharjoittelu- tai projektijaksoilla tai siirryttäessä oppilaitoksesta työhön. Mentorointiohjelmia on toteutettu myös syrjäytymisvaarassa oleville nuorille. Mentoroinnin erilaiset tavoitteet vaativat erilaista mentorointia, joten mentoroinnissa hyödynnetään erilaisia mentoroinnin keinoja (mix of skills). Mentorointi kuvataan usein juuri "kahden kauppana", jossa mentoroinnin onnistumiseen vaikuttavat mentori, aktori ja taustayhteisö.

Vaikka mentoroinnin käsitteellä on paljon erilaisia merkityksiä ja tulkintoja, niistä löytyy yhteinen ydin. Painotuseroista huolimatta mentoroinnin ydinmerkitys tiivistyy ammatilliseksi ohjaussuhteeksi, jossa erilaista osaamista ja kokemusta omaavat henkilöt ovat vuorovaikutuksessakeskenään tavoitteena toisen osapuolen (aktorin) opastaminen ja auttaminen työhön liittyvissä kysymyksissä. Yksiselitteistä ei ole, odotataanko mentorin olevan välttämättä iältään vanhempi kuin mentoroitava. Mentori ei välttämättä aina ole edes merkittävästi kokeneempi. 
Perinteinen käsitys mentoroinnista sisältää konnotaatioita, jotka viittaavat hierarkiseen tai autoritaariseen suhteeseen. Tällaista näkemystä tukee myös käsitteen alkuperäkertomus. Mentoroinnin käsitteen syntytarina on Kreikan mytologiassa, Homeroksen eepoksessa Odysseia. Tarun mukaan Ithakan kuningas Odysseus antoi poikansa Thelemakhoksen vanhan ystävänsä Mentorin hoiviin lähtiessään Troijan sotaan. Mentorin tehtävänä oli auttaa ja ohjata nuorukaista kuninkaan tehtävää, jonka hän oli saanut synnyinlahjakseen. Tarun mukaan itse jumalatar Pallas Athene kätkeytyi Mentorin hahmoon, joten mentorina olikin jumalatar itse (Colley 2001, 182-183; Friday \& Friday 2002, 153-154 .) Alkuperäkertomuksesta alkaen mentoroinnissa näyttää siis korostuvan ajatus huomattavasta suojelijasta, johon liitetään suorastaan jumalallinen arvovalta ja auktoriteetti.

\section{Mentoroinnin etymologia}

Alkuperäkertomuksen Mentorin hahmo synnyttää mielikuvan myyttisestä hahmosta, joka on vanha, viisas ja ystävällinen. Hän toimii pyyteettömästi sijaisvanhemman tehtävässä. Mentori on luotettu neuvonantaja, kouluttaja ja opas, jonka rooliin kuuluu aktorin tukeminen ja suojeleminen sekä roolimallina toimiminen. Mentorointi vaatii mentorilta henkilökohtaisen sitoutumisen nuoremman henkilön kehittymiseen. Suhteessa on vahvasti läsnä molemminpuolinen luottamus ja kunnioitus. (Colley 2001, 186-187.)

Mentorin hahmon myyttisyys saattaa johtaa ongelmiin (Gibb 1994, 32-33; Stokes 2003, 34). Perinteiseen mentoroinnin määrittelyyn sisältyy ajatus holhoavuudesta, riippuvuudesta, hierarkkisesta suhteesta ja tasapainon ylläpitämisestä. Perinteinen määrittely myös korostaa mentorin erityisyyttä (osaaminen, kokemus) ja hänen toimintaansa, jolloin aktorin merkitys jää vähäiseksi. Jos mentorointi nähdään pelkästään kokeneen mentorin olemassa olevan, oikeana pidetyn osaamisen ja tiedon siirtämisenä noviisi aktorille, näin olemassa olevia käytäntöjä vahvistetaan ja kulttuuria säilytetään. Mentorointi saattaa olla myös vallitsevan tasapainon ja valtasuhteiden ylläpitämistä, jolloin mentori varmistaa mentoroinnilla itselle tulevia "liittolaisia". Myyttisen hahmon ongelmana on myös se, että aktori saattaa odottaa mentoroin ratkaisevan ongelmat hänen puolestaan.

\section{Mentorointi dialogina}

Auktoriteettia ja perinnettä korostavan ajattelutavan rinnalle on syntynyt ajatus mentoroinnista tasaveroisena kohtaamisena. Ann Darwinin (2000, 202-209) mukaan mentoroinnin määrittelyssä on kaksi eri näkökulmaa: perinteinen ja radikaalihumanistinen. Perinteisessä näkökulmassa mentori kokeneempana henkilönä jakaa tietojaan ja kokemustaan aktorille, jolloin suhde rakentuu usein yksipuoleiseksi. Tällaisessa suhteessa oppijana on vain aktori.

Radikaalihumanistisen näkökulman mukaan mentorointisuhteen vertaisuus haastaa mentorointia uudistumaan tasavertaiseksi suhteeksi. Tällöin mentorointi on vertaisten yksilöiden kollaboratiivinen, dynamaaminen ja luova suhde, joka perustuu molempien avoimuudelle ja riskinottokyvylle. Tasavertaisuus edellyttää ammatillisten roolien ylittämistä. Mentorointisuhteessa korostuu näin mahdollisuus dialogiin, jolloin raja eksperttiyden ja noviisiyden välillä muodostuu häilyväksi. Suhteen aikuisuutta ja riippumattomuutta korostetaan. Yhteinen oppiminen haastaa yksilöitä ylittämään roolinsa ja olemaan vuorovaikutuksessa kollegiaalisesti. Mentorointisuhde saattaa käynnistyä jonkin konkreetin asian ratkaisemiseksi, mutta yhteisen prosessin myötä se synnyttääkin yhteistä oppimista ja muutosta.

Humanistisesta lähtökohdasta mentoroinnin päämääränä on kasvu autonomisuuteen. Mentoroitava ei voi kasvaa aidosti itsenäiseksi menetelmillä, jotka perustuvat autoritaarisuuteen tai riippuvuuteen toisesta. Tällöin mentoroinnin ihanteena olisi mahdollisimman tasavertainen dialogi. Mentorointi voisi siis olla parhaimmillaan kahden ihmisen välistä vuorovaikutusta, joka perustuu vastavuoroiseen luottamukseen ja toisen tietojen, taitojen ja osaamisen arvostamiseen.

Dialogisuuden käsite juontuu kreikan kielen sanoista dia ja logos. Sanoilla on useita merkityksiä kreikan kielessä. Yksinkertaisimmillaan dia merkitsee lukusanaa kaksi ja logos tarkoittaa sanaa tai puhetta, jolloin dialogi tarkoittaa kaksinpuhelua. Dialogisuus saa kuitenkin laajemman sisällön kantasanojen muista merkityksistä. Ensinnäkin dia tarkoittaa lukusanan lisäksi prepositiota: kautta, läpi tai välillä. Logos-sanan laajemmat merkitykset ovat olleet pitkään filosofien ja teologien kiistakysymyksenä, mutta sana viittaa ainakin merkkiin, merkitykseen, ymmärrykseen, tarkoitukseen ja tulkintaan - yleensä 
sellaiseen, jonka voi välittää sanojen ja puheen avulla toiselle.

Sanaan logos liittyy niinkin perustavia merkityksiä, että se voidaan liittää koko elämän tarkoitukseen ja kaikkeuden alkuperään. Raamatussa logos esiintyy esimerkiksi Johanneksen evankeliumin alussa: "Alussa oli sana, ja sana oli Jumala."

Dialogi on siis laajasti määriteltynä keskustelua, jossa inmiset rakentavat yhdessä merkitystä, tarkoitusta tai ymmärrystä (logos), etsivät mieltä ja tulkintaa elämälleen ja maailmalleen. Logos syntyy välitilassa (dia) - ihmisten kautta, välillä ja läpi -joten se ei ole kenenkään omaa. Logos ei myöskään koskaan ole lopullisesti valmis, vaan se virtaa ja liikkuu ihmisten keskustellessa. (Heikkinen 2005.)

Dialogi on siis aidosti dynaamista, eteenpäin virtaavaa. Se on kuin peli, jota pelaajat eivät täysin hallitse. Dialogin osapuolet eivät itsekään kokonaan tajua sitä, millä logiikalla dialogi etenee, vaan keskustelu vie mukanaan näennäisen sattumanvaraisesti uusiin ideoihin ja mielen maisemiin. Martin Buberin tapaan sanottuna dialogisuus on Sinä-Minä-suhde, jossa dialogi rakentuu Minän ja Sinän väliseen tilaan. Tällaisessa suhteessa kumpikaan osapuoli ei näe toistaan toimintansa kohteena tai välineenä toisin kuin monologisessa Minä-Se -suhteessa, jossa toista ihmistä käytetään välineenä omien päämäärien saavuttamiseksi. Dialogisessa Minä-Sinä-suhteessa toista inmistä kohdellaan Immanuel Kantin kategorisen imperatiivin sanoin päämääränä sinänsä, ei välineenä (Kant 1990, 110; Buber 1993, 25-27; Huttunen 1995.)

Dialogissa merkitykset ja tulkinnat rakentuvat siis yhteisessä välitilassa - kohtaamisen sfäärissä. Dialogi virtaa, siinä virrassa ollaan mukana, eikä kumpikaan keskustelija hallitse sitä omalla tahdollaan. He jättäytyvät virran vietäviksi, joka vie heitä kohti uusia mielen ulottuvuuksia. Tätä dialogisuuden autopoieettisuutta - kasvua omilla ehdoillaan - kuvaa metafora dialogista pelinä tai leikkinä. Dialogi on kuin peli tai leikki, johon pelaaja heittäytyy mukaan. Aito leikki etenee omilla ehdoillaan, eikä kukaan sen osallistujista voi määrätä täysin sen kulkua. (Huttunen 2003, 132-133; Gadamer 1975, 97-98.)

Mentori ei siis "siirrä" toiselle oikeaa näkemystä tai tietoa, vaan rakentaa merkityksen ja tulkinnan yhdessä toisen ihmisen kanssa. Mentori on nöyrä elämän edessä. Hän välttää asettumasta rooliin, jossa asettaisi oman elämänsä ratkaisut ja uskomukset lähtökohdiksi toisen ihmisen hyvälle elämälle. Aidossa dialogissa myös mentori oppii keskustelussaan mentoroitavan kanssa. Dialogiin liitetään tasa-arvoisuuden vaatimus: dialogissa keskustelevat kohtelevat toisiaan vertaisinaan. Dialogisessa suhteessa kukaan ei omista toistaan parempaa tai pätevämpää näkökulmaa todellisuuteen, vaan molemmat myöntävät käsitystensä keskeneräisyyden ja ehdotusluontoisuuden. Dialogi kunnioittaa toisen ihmisen autonomiaa, molemmilla on oikeus olla oma itsensä. (Heikkinen 2005.)

\section{Vertaisuutta eri tasoilla}

Vaatimus täydellisestä vertaisuudesta mentorin ja mentoroitavan välisessä dialogissa johtaa kuitenkin nopeasti sekä teoreettisiin että käytännön ongelmiin. Käytännön tasolla se saattaa pahimmillaan johtaa naiiveihin odotuksiin täydellisestä kohtaamisesta, jolloin reaalimaailman raadollisuus saattaa tyrehdyttää nopeasti koko prosessin. Teoreettisella tasolla vaatimus täydellisestä vertaisuudesta johtaa pedagogisena paradoksina tunnettuun umpikujaan: miten on mahdollista ohjata autonomiaan toista ihmistä, joka jo oletetaan autonomiseksi?

Ehdotamme mentoroinnin tarkasteluun mallia, joka auttaa välttämään toisaalta autoritaarisuuden ja hierarkkisuuden, toisaalta naiivit odotukset täydellisestä tasavertaisuudesta. Teoreettista dilemmaa pedagogisesta paradoksista se ei toki ratkaise, mutta näyttäisi auttavan sen kiertämiseen siten, että käytännön tasolla on helpompi löytää hedelmällisiä ratkaisuja. Mentoreiden kouluttajina saamiemme kokemusten mukaan on hyödyllistä tarkastella vertaisuutta erikseen eksistentiaalisella, episteemisellä ja juridis-eettisellä tasolla.

Kehittämässämme mallissa on sovellettu Axel Honnethin (1996) teoriaa tunnustuksen dialektiikasta, Anita Malisen (2000) ajatusta aikuisopettajan vastuista sekä Pierre Bourdieun (1992, 1994) ideoita tietämisen kentistä ja pääomasta.

Eksistentiaalinen vertaisuus merkitsee sitä, että ihmisenä olemisen, eksistenssin tasolla inmiset ovat tasavertaisia. Eksistentiaalisella tasolla mentorin ja aktorin suhde on siis symmetrinen. Episteemisellä tasolla eli tietojen, taitojen ja kokemusten suhteen inmiset puolestaan eivät ole tasavertaisia. Tietoja, taitoja tai kokemuksia jolla- 
kulla on enemmän kuin toisella tai ne ovat sisällöltään erilaisia, joten episteemisellä tasolla mentorointisuhde on epäsymmetrinen. Juridis-eettisellä tasolla on sekä epäsymmetrisiä että symmetrisiä suhteita. Joissakin tilanteissa mentorilla on enemmän lakeihin ja säädöksiin perustuvaa vastuuta kuin mentoroitavalla. Joissakin tilanteissa taas juridis-eettinen vastuu on mentorointisuhteessa tasavertainen.

Tiivistelmä mallista esitetään taulukossa 1. Täytyy huomata, että vertaisuuden eri tasot ovat läsnä yhtä aikaan lomittain, eivätkä ne ole toisiaan poissulkevia ulottuvuuksia. Mentorointisuhteessa mentoria kuvataan symbolilla $\mathbf{M}$ ja aktoria mentoroitavaa symbolilla $\mathbf{A}$

\section{EKSISTENTIAALINEN VERTAISUUS-ole-} massaolo; inmisarvo

- SYMMETRIAM = A: mentori ja aktori yhdenvertaisia eksistentiaalisella tasolla

2. EPISTEEMINEN VERTAISUUS - tieto; asiantuntijuus

- oman asiantuntijuutensa kentällä mentori on ylivertainen:

- ASYMMETRIA M > A: mentorilla enemmän pääomaa

- jollain muulla kentällä aktori voi olla ylivertainen:

- ASYMMETRIA M < A aktorilla enemmän pääomaa

3. JURIDIS-EETTINEN VERTAISUUS - vastuut, oikeudet ja velvollisuudet

- ASYMMETRIAM > A: mentorilla joissakin tilanteissa enemmän vastuuta

- SYMMETRIAM = A, mentori ja aktori jakavat vastuun

\section{Taulukko 1. Vertaisuuden tasot mentoroinnissa.}

\section{Aineisto}

Tarkastelemme näitä vertaisuuden eri tasoja ja niiden esiintymistä kahden eri aineiston näkökulmasta. Molemmat aineistot on kerätty osana monitieteisiä mentor-opintoja (5 ja 15 ov), jotka Jyväskylän yliopiston avoin yliopisto toteutti kasvatustieteen tiedekunnan vahvistaman opetussuunnitelman mukaisesti. Aineisto on kerätty mentor-opintoihin osallistuneilta opiskelijoilta.

Yhden aineistokokonaisuuden muodostaa kah- den eri mentor-opintoja opiskelevan ryhmän verkkokeskustelut. Keväällä 2003 toteutettuun verkkokeskusteluun osallistui 23 henkilöä, jotka olivat eri toimintaympäristöjen asiantuntijoita. Useimmat heistä vastasivat oman työpaikkansa henkilöstön kehittämisestä tai he toimivat ammatillisten oppilaitosten ja ammattikorkeakoulujen opiskelijoiden ohjaustehtävissä. Osallistujia pyydettiin tarkastelemaan seuraavia teemoja: mitä mentorointi on, mitä mentorointiin kuuluu/mitä siiten ei kuulu, miten mentorointi eroaa muista ohjauksen muodoista (esimerkiksi perehdytys, työnohjaus, opetus) ja miten mentorointia voisi soveltaa omassa työyhteisössä?

Toinen aineistokokonaisuus on kerätty mentor-opintojen päätteeksi 22 terveydenhuollon sektorilla toimineelta mentorilta. Palautteen kysymykset olivat seuraavat: mikä on mentoroinnin ydin, mitä mentorointi on antanut itselle, mitä mentorointi on antanut aktoreille, mitkä ovat oman kokemuksen mukaan mentoroinnin "menestystekijät? Mentorit olivat toteuttaneet ryhmämentorointia 1,5 vuoden ajan palvelutalojen henkilöstölle. Palauteaineisto on kerätty keväällä 2006.

\section{Milla ehdoin vertaisuus on mahdollista?}

Eksistentiaalisella vertaisuudella tarkoitamme inmisten välisten suhteiden yleisinhimillistä tasavertaisuutta. Humanistinen inmiskäsitykseen perustuva yksilölähtöinen ohjauksen filosofia lähtee periaatteesta, jonka mukaan jokainen yksilö on ainutlaatuinen ja arvokas. Jokaisella ihmisellä on oma ominainen luontonsa, jota hän pyrkii toteuttamaan niin kokonaisesti ja täysin kuin on mahdollista. Humanismi uskoo inmisen haluun ja kykyyn kehittyä. (Hirsjärvi 1984, 108109.) Eksistentiaalisella tasolla kenenkään elämä ei ole sellaisenaan arvokkaampi kuin toisen inmisen elämä. Jokaisella yksilöllä on oikeus inhimilliseen arvokkuuteen. Kukaan ei ole ihmisenä toistaan arvokkaampi, vaan jokainen ihmiselämä on yhtä ainutlaatuinen ja arvokas sellaisenaan.

Humanistisesta lähtökohdasta eri henkilöiden inmisyyttä ja olemassaolon arvoa ei voi vertailla. Tällä ulottuvuudella ihmisten väliset suhteet ovat aina symmetrisiä. Tätä voidaan nähdäksemme pitää lähtökohtana myös mentorointisuhteessa. Mentori ja aktori ovat inmisolentoina tasa- 
vertaisia, yhtä arvokkaita riippumatta heidän koulutus- ja työkokemustaustastaan tai asemastaan yhteisössä.

Ajatus eksistentiaalisen vertaisuuden tarkastelemisesta erillään asiantuntijuudesta saa tukea Axel Honnethin (1996) tunnustuksen dialektiikan teoriasta. Honnethin mukaan ihmiset kamppailevat tunnustuksen saamiseksi monin eri tavoin. He tarvitsevat tunteen, että heidät hyväksytään ihmisinä, heistä välitetään ja heitä rakastetaan sellaisenaan. Mentoroitavan ja mentorin dialogin lähtökohtana on siis vastavuoroinen tunnustuksen antaminen eksistentiaalisella tasolla. Toimivaa mentorointisuhdetta on vaikea edes kuvitella, jos toisen osapuolen ihmisarvo asetetaan kyseenalaiseksi.

Verkkokeskustelussa eksistentiaalinen vertaisuus ilmeni verkkokeskustelussa oppimisen mahdollisuuksien molemminpuolisuuden korostamisena. Vaikka mentoroinnissa aktorin kehittyminen onkin tavoitteena, odottivat mentoreiksi kouluttautuvat myös itse oppivansa ja kehittyvänsä mentorina, ihmisenä ja työntekijänä. Mentorina toimiminen antaa työntekijälle mahdollisuuden tarkastella omaa työn tekemisen tapaansa ja omia käsityksiään uudella tavalla. Vuorovaikutuksessa oppii kyseenalaistamaan omia ajatuksiaan ja hylkäämään sellaista toimintatapoja, jotka eivät enää toimi. Näin mentori ei asettaudu aktorin yläpuolelle, vaan on oppimisessaan vertainen. Omaa tietämystä ja taitoja ollaan valmiita jakamaan, mutta samalla itse halutaan oppia aktorilta heidän hallitsemiaan asioita. Aktoreille annetaan tunnustusta heidän osaamisestaan, sillä heidän tiedetään olevan mentoria parempia joissakin asioissa.

Terveydenhuollon sektorilla toimineet mentorit pohtivat mentoroinnin eksistentiaalista vertaisuutta lähinnä kahdesta eri suunnasta. Ensinnäkin ryhmässä toteutettu (mentori + 4-6 aktoria, jotka ovat samasta työpaikasta) mentorointi on luonut foorumin ja mahdollisuuden puhua ääneen omia mielipiteitään ja näkemyksiään mentorin johdolla kollegoiden kanssa. Rauhallisen keskustelutilanteen luominen ja tasavertainen ajatusten ja kokemusten vaihto on ollut tärkeää aktoreille. Työyhteisössä on opittu, että voidaan luottamuksellisesti keskustella arkipäivän pienistä asioista tulematta muiden taholta nolatuksi.

Toiseksi eksistentiaalinen vertaisuus tulee esille vastavuoroisen tunnustuksen antamisena tehdystä työstä. Mentorit ovat keskustelujen myötä todenneet, että palvelutalojen henkilöstö on työhönsä sitoutunutta ja tekee työnsä parhaalla mahdollisella tavalla juuri siinä toimintaympäristössä.

\section{Ihmiset eri asemassa tietämisen ja osaamisen suhteen}

\section{Epistemologisella vertaisuudellatarkoitamme} sitä, kuinka osapuolet ovat tasaveroisessa tai erilaisessa asemassa tietämisen tai osaamisen suhteen jollakin elämänalueella. Axel Honnethin (1996) tunnustuksen dialektiikan teoriassa tämä tulee esille siinä, että ihmiset kaipaavat myös tunnustusta oman työnsä arvokkuudesta ja merkityksellisyydestä. Työn kautta saatava tunnustus on jokaiselle tärkeä itsearvostuksen lähde.

Tällä tasolla inmiset eivät kuitenkaan ole tasaveroisia, vaan joillakin on tietoa ja osaamista enemmän ja se on sisällöltään erilaista kuin toisilla. Dialogisuuden lähtökohdaksi on siis naiivia olettaa episteemistä vertaisuutta. Joskus kuitenkin voi olla myös niin, että mentoroitava on saavuttanut jollakin tavalla arvostettavaa kokemusta enemmän kuin mentori. Valaistaksemme tätä tarkemmin sovellamme Pierre Bourdieun $(1992,1994)$ ajatusta tiedon kentistä ja pääomista. Esimerkiksi tietotekniikan hallinta on oma kenttänsä, taidehistoria tai mopon korjaamisen taito omansa. Jokaisella näillä kentällä alkupääoma alkaa kasvaa lisäarvoa - pääoma tulee pääoman luokse, kuten talouselämässäkin. Mitä enemmän tiedät tai osaat jonkin kentän asioista, sen paremmat mahdollisuudet sinulla on hankkia lisää tietoa tältä samalta kentältä. Taidehistorian kentällä hankittu pääoma ei kuitenkaan auta kovin paljoa mopon moottorin korjauksessa tai päinvastoin. Bourdieun ajattelussa korostuu kamppailun asetelma ja pyrkimys saavuttaa asema kentällä muihin kilpailijoihin nähden. Tässä esityksessä emme kuitenkaan korosta monopolin tai kamppailun asetelmia, vaan sovellamme kentän ja pääoman käsitteitä vähemmän taisteluhenkiseen tapaan.

Kentän ja pääoman käsitteet auttavat ymmärtämään, että joidenkin asioiden suhteen mentoroitavalla saattaa olla joistakin asioista tietoja ja kokemusta, joka tekeekin hänestä ylivertaisen mentoriin nähden. Mentori on luonnollisesti ylivertainen omalla kentällään. Hänellä on jotain ainutlaatuista, hiljaiseksi tiedoksi sedimentoitunutta kokemusta omalta alaltaan. Jollain toisella 
episteemisellä kentällä-vaikkapa tietotekniikassa tai internetin käytössä - mentoroitavalla saattaa olla enemmän vaihtoarvoista tiedon pääomaa. Tyypillinen esimerkki on internetin käyttö tiedonhakuun. Nuoremmilla sukupolvilla on myös ikäistensä elämänmuodon tuntemukseen liittyvää pääomaa - nuorisokulttuurin merkitysten ja trendien tajua - josta saattaa olla merkittävästi hyötyä muiden käyttökelpoisten pääomien kartuttamisen kannalta vaikkapa tuotteiden markkinoinnissa nuorisolle.

Episteemisessä vertaisuudessa on siis monta mahdollisuutta - suhde voi olla asymmetrinen joko mentorin tai mentoroitavan eduksi monin eri tavoin. Mentorin ja mentoroitavan suhteessa tätä voidaan tietoisestikin hyödyntää: molemmilla osapuolilla mahdollisuus oppia toisiltaan ja kartuttaa yhdessä lisää pääomia sen sijaan, että he kamppailisivat keskenään. Onnistuneen mentorointisuhteen avaimena kuitenkin on havainto, että osapuolet voivat antaa tunnustuksen toistensa erilaisista pääomista.

Mentor-opintojen verkkokeskusteluissa pohdittiin paljon mentorin ja aktorin erilaisten pääomien merkitystä mentorointisuhteelle. Tiedon, taidon tai osaamisen erilaiset pääomat luovat yhteiselle keskustelulle jännitteen, joka vie keskustelua eteenpäin. Keskusteluun syntyy riittävästi toiseutta, jotta oma ajattelu rikastuisi. Dialoginen suhde vaatii riittävän määrän erilaisuutta. Jos ajatusten ja kokemusten samuutta on liikaa, hedelmällinen ja erilaista lähtökohdista kumpuava vuorovaikutus ei ole mahdollinen. Miten tätä mentorin ja aktorin erilaisuutta keskustelussa pohdittiin?

Jotkut mentoreiksi kouluttautuvat kuvasivat omaa auktoriteettiasemaansa tietotaidon tuomana auktoriteettina. Oma asiantuntijuus koettiin niin vahvaksi, että mentorina pystyy toimimaan aidosti omana itsenä. Tähän sisältyy ajatus siitä, että oma osaaminen riittää eikä tarvitse pinnistellä ollakseni jotakin erikoista, vaan omat kokemukset ovat sinällään jakamisen arvoisia ja jollekin mahdollisesti avuksi. Oppimisen molemminpuolisuus mahdollistuu vain silloin, kun pääoma on riittävän erilaista. Pääomat eivät ole toistaan arvokkaampia ja määräävämpiä, vaan osapuolet voivat antaa tunnustusta toistensa erilaisista pääomista.

Mentoroinnin ongelmaksi verkkokeskustelussa mainittiin taistelu kentän rajojen ja rakenteiden ylläpitämiseksi, jolloin omaa tietämystä var- jellaan. Rajojen ja rakenteiden ylläpitäminen saa ainakin kahdenlaisia ilmenemismuotoja. Ensinnäkin työpaikkojen "antimentoroinnin" ilmapiiri saattaa olla esteenä hedelmälliselle mentoroinnille. Antimentoroinnilla tarkoitetaan asennetta, jossa omaa osaamista ei haluta antaa muiden käyttöön. Kentällä saavutettu arvostettu pääoma halutaan pitää henkilökohtaisena omaisuutena. Oman pääoman panttaamisella saadaan vahvistettu omaa hallitsevaa asemaa kentällä.

Toiseksi kentän rajojen ja rakenteiden ylläpitäminen ilmenee mentorointisuhteissa, joissa mentori direktiivisesti ohjaa aktoria omien tavoitteidensa suunnassa. Mentorin tehtävänä ei tällöin olekaan aktorin henkilökohtaisen ja ammatillisen kehityksen tukeminen ja kannustaminen, vaan oman aseman vahvistaminen kentällä saamalla itselle sopiva liittolainen. Mentorin tavoitteena saattaa näin olla tunnustuksen hakeminen oman työn arvokkuudesta ja merkityksellisyydestä kyseenalaisin keinoin - aktoria pakottamalla.

Terveydenhuollon sektorin mentoreiden palautteessa episteeminen erilaisuus tuli esille nimenomaan erilaisten toimintaympäristöiden osaamisena. Mentorit edustivat erikoissairaanhoidollista hoito-osaamista ja aktorit palvelutalojen hoivaosaamista. Eri toimintaympäristössä toiminnan logiikat ovat erilaisia, ja tämä täytyy tunnustaa toimivassa mentorointisuhteessa. Mutta mentoreilla oli sisällöllistä ja toiminnallista osaamista myös palvelutalon henkilöstölle jaettavaksi. Mentorit ovat yhteisen keskustelun ja pohdinnan lisäksi ohjaustilanteissa antaneet uutta tietoa psyykkisistä sairauksista ja lääkityksestä. Aktorit ovat puolestaan laajentaneet mentoreiden käsityksiä hoitotyön arjesta palvelutaloissa, ja näin heille on muodostunut käsitys siitä millainen psykiatrinen hoito palvelutaloissa on mahdollista.

\section{Oikeuksien ja velvollisuuksien tunnistaminen ja tunnustaminen}

Juridis-eettinen vertaisuus tarkoittaa sitä, kuinka laillisia ja eettisiä vastuita kannetaan mentorin ja mentoroitavan rooleissa. Axel Honnethin teorian mukaan yksilöiden lailliset oikeudet tulee tunnustaa ja tunnistaa, samoin velvollisuudet. Tässä yhteydessä tulee erityisesti esille Honnethin teorian suomentamisen vaikeus, koska sekä saksassa (anerkennen) että englannissa (re- 
cognise) verbi tarkoittaa sekä tunnistamista että tunnuksen antamista.

Juridis-eettisellä tasolla on siis kysymys oikeuksien ja velvollisuuksien tunnistamisesta ja tunnustamisesta. Juridis-eettinen vertaisuus on joissakin tapauksissa epäsymmetrinen, kun taas joissakin tilanteissa suhde on vahvasti symmetrinen.

Epäsymmetrisessa suhteessa mentorilla on enemmän vastuita, oikeuksia ja velvollisuuksia kuin aktorilla. Esimerkiksi opetusharjoittelutilanteessa ohjaaja on vastuussa juridisesti siitä, miten opetus järjestetään. Jos opiskelija lähtee oppilaiden kanssa pyöräretkelle ja tapahtuu onnettomuus, ohjaaja joutuu vastuuseen turvallisuusjärjestelyjen riittävyydestä. Väitöskirjan ohjaajan roolissa mentori kantaa myös juridista vastuuta siitä, että väittelijä etenee työssään hyvää tieteellistä tapaa noudattaen. Usein mentori on virkamiehenä virkavastuussa, mutta mentoroitava kantaa vastuuta vähemmän. Juridisessa mielessä mentorin ja mentoroitavan välinen suhde on siis usein epätasaveroinen: se on juridisesti asymmetrinen siten, että mentori joutuu monissa tapauksissa kantamaan vastuuta lain edessä enemmän kuin mentoroitava. Myös moraalisessa mielessä mentorilta odotetaan usein enemmän.

Juridis-eettinen vertaisuuden ulottuvuudella ei ole kaikissa mentorointisuhteissa ratkaisevaa merkitystä. Tällöin ei synny ongelmia, jotka juontuisivat erilaisista eettisistä tai moraalisista vastuista, vaan vastuu on yhteisesti jaettu. Symmetrisessä suhteessa yhteinen vastuunkanto sisältää esimerkiksi työskentelyn mentorointisuhteen onnistumiseksi. Dialogisuuden onnistumiseksi on tarpeen tunnistaa jo alkuvaiheessa ne velvollisuudet, jotka kehystävät mentorointiprosessia. Monet suosittelevat (Juusela ym. 2000, 207; Murray 2001; Nakari ym. 1996, 35), että mentoroinnista tehdään sopimus joko suullisesti tai kirjallisesti. Yhteisesti laadittu mentorointisopimus on luottamuksellisen suhteen perusta: yhteisesti sovitaan tavoitteet, tapaamispaikka ja-ajankohdat sekä "pelisäännöt". Mentorointi onnistuu, jos molemmat osapuolet ovat sitoutuneet ja toimivat luottamuksellisesti. Mentorointisuhde perustuu vapaaehtoisuuteen, mutta se ei suinkaan tarkoita ettei toisesta kannettaisi vastuuta tai suhde olisi sattumanvarainen.

Terveydenhuollon sektorin mentorit pohtivat palautteessaan mentoroinnin tavoitteita eettisenä kysymyksenä. Aktorit saattavat asettaa mentorille sellaisia odotuksia, johon ei voi vastata.
Mentorin voidaan odottaa ratkaisevan työpaikalla olevat "ideologiset" ristiriidat (esimerkiksi kysymys siitä mitä on hyvä hoito, miten vanhuksen lähiomaisiin suhtaudutaan, miten johtaminen pitäisi työyhteisössä toteuttaa). Lisäksi palvelutaloissa saattaa olla sellaisia asukkaita, joita ei voida enää hoitaa palvelutalossa, mutta jotka eivät myöskään hyödy erikoissairaanhoidosta. Eli millainen hoito ja hoiva on heille parasta? Tällaiset kysymykset eivät ole vain mentorin ja aktorin tai edes heidän työyhteisössä ratkaistavia kysymyksiä, vaan se nostaa keskustelun yhteiskunnalliselle tasolle. Terveydenhuollon sektorilla näitä kysymykset liittyvät siihen, että keitä hoidetaan, missä heitä hoidetaan, miten hoito resursoidaan ja kuinka henkilöstön osaamisesta huolehditaan?

\section{Lopuksi}

Tässä artikkelissa on tarkasteltu mahdollisuutta tasavertaiseen dialogiin mentoroinnissa. Tasavertaisuutta on jäsennetty eksistentiaalisena, episteemisenä ja juridis-eettisenä vertaisuutena. Mentorointisuhteesta voidaan löytää näiden ulottuvuuksien suhteen sekä symmetriaa että epäsymmetriaa. Kehittymistä tukeva mentorointisuhde edellyttää näiden tasavertaisuuden ja epätasavertaisuuden samanaikaista läsnäoloa. Tämä vaatii mentorilta sitä, että hän hyväksyy ristiriitaisten elementtien yhtäaikaisen läsnäolon. Ristiriidan sietämistä saattaa helpottaa havainto, että yksilöt ovat inmisinä tasavertaisia, vaikka asiantuntijuuden suhteen ollaankin eriarvoisia.

Episteemisellä tasolla inmiset ovat epäsymmetrisiä, koska heillä on erilaisia tietoja, taitoja tai kokemuksia. Riittävä määrä erilaisuutta ja toiseutta on mentorointisuhteen perusedellytys. Mentorointisuhdetta tuskin edes syntyy, jollei osaamisen erilaisuutta ole olemassa. Dialogisuuden edellytyksenä on optimitila toiseuden ja samuuden välillä - eli riittävä määrä samuutta, jotta keskustelu onnistuu ja on mielekästä, mutta riittävän määrä toiseutta, jotta toisen näkökulmat voivat rikastuttaa omia. Siksi mentorin löytäminen jostain muusta kuin omasta työyhteisöstä saattaa olla hyödyllistä.

Tasaveroinen ja dialoginen mentorointisuhde luo tiettyjä edellytyksiä myös aktorille. Aktorin haasteena on se, ettei hän odota mentorilta yksiselitteisiä ja valmiita ohjeita ja neuvoja, vaan mentorointisuhde edellyttää aktorilta kriittistä 
asennetta mentorin ajatuksille. Aktorin ei pitäisi olettaa, että mentori tekee asioita hänen puolestaan tai "päästää hänet pälkähästä", vaan hänellä itsellään on vastuu omasta kehittymisestään.

\section{Lähteet}

Baldassare, V. \& Laneve, C. (1998). L'anno di formazione degli insegnanti. Indagine comparativa in Europa e proposte di innovazione. Comparative study of induction programmes for beginning teachers in Europe: International comparison of mentoring.) Università Degli Studi di Bari. Dipartimento di Science Dell'Educatszione.

Bourdieu, P. \& Wacquant, L. (1992). An invitation to reflexive sociology. Cambridge: Polity Press.

Bourdieu, P. (1994). In other words: Essays towards a reflexive sociology. Cambridge: Polity Press.

Buber, M. (1993). Minä ja Sinä. WSOY.

Colley, H. (2001). Righting rewritings of the myth of Mentoring: a critical perspective on career guidance mentoring. British Journal of Guidance and Counselling 29, 2, 176-197.

Darwin, A. (2000). Critical reflections on mentoring in work settings. Adult Education Quarterly50, 3, 197-211.

Friday, E. \& Friday, S. (2002). Formal mentoring: is there a strategic fit? Management Decision 40, 2, 152-157.

Gadamer, H.G. (1975). Wahrheit und Methode. Germany: Mohr Tübigen.

Gibb, S. (1994). Evaluating mentoring. Education \& Training 36, 5, 32-39.

Heikkinen, H. (2005a). Ikä on mentorin viisaus. Aikuiskoulutuksen maailma 81 (1), 21.

Heikkinen, H. (2005b). Mistä tulet, mentori? Aikuiskoulutuksen maailma 81 (2), 19.

Heikkinen, H. (2005c). Mentorointi on lämmin kädenojennus. Opettaja (34), 14-15.

Hirsjärvi, S. (1984). Kasvatusfilosofia ja ihmiskäsitys. Jyväskylän yliopiston kasvatustieteen laitoksen julkaisuja B 5.

Honneth, A. (1996). Struggle for recognition. The moral grammar of social conflicts. Oxford: Polity Press.
Huttunen, R. (1995). Dialogiopetuksen filosofia. http://www.cc.jyu.fi/ rakahu/ tiedepol.html

Huttunen, R. (2003). Kommunikatïvinen opettaminen - Indoktrinaation kriittinen teoria. Sophi.

Jokinen, H. \& Sarja, A. 2005. Mentorointi uusien opettajien ja uuden opettajuuden tukena. Käsikirjoitus teokseen J. Välijärvi \& A.-R. Nummenmaa.

Juusela, T., Lillia, T. \& Rinne, J. (2000). Mentoroinnin monet kasvot. Yrityskirjat Oy.

Kant, I. (1993). Siveysopilliset pääteokset. WSOY.

Leskelä, J. (2005). Mentorointi aikuisopiskelijan ammatillisen kehittymisen tukena. Acta Universitatis Tamperensis 1090, Tampereen yliopisto.

Malinen, A. (2000). Towards the essence of adult experiential learning. SoPhi.

Mentor-opintokokonaisuus (2005). Jyväskylän yliopiston avoimen yliopiston mentor-opintokokonaisuuden esittely. Haettu 21.1.2005 osoitteesta http://www.avoin.jyu.fi/mentor/ esittely.htm

Murray, M. (2001). Beyond the myths and magic of mentoring: how to facilitate an effective mentoring process. San Francisco: JosseyBass.

Nakari, L., Porenne, P., Mansukoski, S. \& Huhtala, T. (1998). Mentorointi: johdon ja asiantuntijuuden kehitysmenetelmä. Ekonomia.

Stokes, P. (2003). Exploring the relationship between mentoring and counselling. British Journal of Guidance and Counselling 31, 1, 25-38.

Tunkkari-Eskelinen, M. (2005). Mentored to Feel Free: Exploring Family Business Next Generation Members' Experiences of NonFamily Mentoring. Jyväskylä Studies in Business and Economics 44.

Vuorinen, R. (2004). Mentorointi yleistyy. Ekonomi (8),19.

Artikkeli saapui toimitukseen 19.12.2005. Se hyväksyttiin julkaistavaksi toimituskunnan kokouksessa 12.5.2006. 